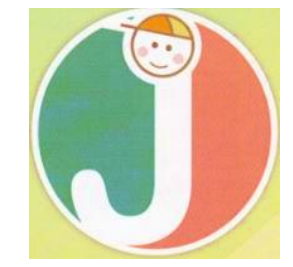

\author{
JEA (JURNAL EDUKASI AUD) \\ PENDIDIKAN ISLAM ANAK USIA DINI \\ UNIVERSITAS ISLAM NEGERI ANTASARI BANJARMASIN \\ DOI: 10.18592/jea.v7i1.4558
}

Received: 24032021 / Accepted: 26062016 / Published online: 27062021

\title{
ANALISIS PERMASALAHAN GURU PAUD \\ PADA PEMBELAJARAN DARING (DALAM JARINGAN) DI MASA PANDEMI COVID-19
}

\author{
Yesi Novitasari ${ }^{1}$, Reswita ${ }^{2}$, Sean Marta Efastri ${ }^{3}$ \\ Prodi Pendidikan Guru PAUD, Universitas Lancang Kuning \\ E-mail: yesinovitasari@unilak.ac.id
}

\begin{abstract}
This study aims to describe the problems faced by PAUD teachers in implementing online learning during the COVID-19 pandemic, especially in Tenayan Raya District. This type of research is descriptive research. The population in this study amounted to 37 teachers. The data collection technique in this study used a questionnaire, while the data analysis technique used quantitative descriptive analysis. Based on the results of the study, it can be concluded that there are problems in the online learning process during the Covid-19 pandemic in Tenayan Raya District. For indicators of material organization, children's positive attitude, and learning flexibility are in the low category. While the indicators of communication (online), mastery and enthusiasm and learning outcomes are categorized as many.
\end{abstract}

Keywords : Teacher Problems, Online Learning, Early Childhood.

\begin{abstract}
Abstrak
Penelitian ini bertujuan untuk mendeskripsikan tentang permasalahan-permasalahan yang dihadapi guru PAUD dalam melaksanakan pembelajaran dalam jaringan (daring) pada masa pandemi covid-19 khususnya di Kecamatan Tenayan Raya. Jenis penelitian ini merupakan penelitian deskriptif. Populasi pada penelitian ini berjumlah 37 guru. Teknik penggumpulan data pada penelitian ini menggunakan kuisioner, sedangkan teknik analisis data menggunakan analisis deskriptif kuantitatif. Berdasarkan hasil penelitian dapat disimpulkan bahwa terdapat
\end{abstract}




\begin{abstract}
permasalahan dalam proses pembelajaran daring pada masa pandemi Covid-19 di Kecamatan Tenayan Raya. Untuk indikator pengorganisasian materi, sikap positif anak, dan keluwesan pembelajaran berada dalam kategori sedikit. Sedangkan indikator komunikasi (daring), penguasaan dan antusiasme dan hasil belajar dikategorikan banyak.
\end{abstract}

Kata Kunci : Permasalahan Guru, Pembelajaran Daring, Anak Usia Dini

\title{
Pendahuluan
}

Guru Pendidikan Anak Usia Dini (PAUD) adalah pendidik profesional dengan tugas utama mendidik, mengajar, membimbing, mengarahkan, melatih, menilai, dan mengevaluasi peserta didik pada anak usia dini dengan rentang usia 0-6 tahun. Guru menjadi salah satu komponen penting dalam dunia pendidikan. Hal ini dikarenakan guru merupakan titik sentral didalam tenaga kependidikan yang berhubungan langsung dengan peserta didik sehingga dijadikan sebagai tauladan bagi peserta didik. Keberhasilan penyelenggaraan pendidikan sangat ditentukan oleh kesiapan guru dalam mempersiapkan peserta didik melalui proses pembelajaran. Adanya virus covid-19 pada tahun 2020 memberikan dampak yang luar biasa hampir pada semua bidang, salah satunya pada bidang pendidikan.

Untuk melawan Covid-19 pemerintah telah melarang untuk berkerumun, pembatasan sosial (social distancing) dan menjaga jarak fisik (physical distancing), memakai masker dan selalu cuci tangan. Melalui Kementerian Pendidikan dan Kebudayaan Pemerintah telah melarang sekolah untuk melaksanakan pembelajaran tatap muka (konvensional) dan memerintahkan untuk menyelenggarakan pembelajaran secara daring. Dengan adanya virus covid-19 ini membuat proses pembelajaran menjadi 
berubah dari yang tatap muka menjadi pembelajaran jarak jauh, tetapi dalam keadaan seperti ini pun guru masih tetap harus melaksanakan kewajibanya sebagai pengajar, dimana guru harus memastikan anak dapat memperoleh informasi/ilmu pengetahuan.

Untuk mencapai tujuan tersebut guru harus memahami cara atau langkah yang harus diikuti sehingga tujuan yang ditetapkan tercapai. Salah satu cara yang dilakukan adalah dengan menerapkan pembelajaran daring (dalam jaringan). Pembelajaran daring merupakan pembelajaran tanpa tatap muka secara langsung antara guru dan anak, tetapi dilakukan melalui online.

Pembelajaran daring memang membutuhkan tanggung jawab, kemandirian dan ketekunan pribadi, karena tidak ada yang mengontrol selain dirinya sendiri. Pembelajaran daring juga membutuhkan peran serta orangtua untuk mendampingi serta menyediakan media yang diperlukan.

Sebagai guru tentunya akan berusaha agar apa yang diajarkan dapat dimengerti dan dipahami melalui berbagai cara, strategi, dan metode. Sekalipun dimasa pandemi covid-19, perjuangan seorang pendidik tidak dapat diruntuhkan meski terpaut jarak dan waktu pada anak didik. Namun, kenyataan yang dihadapi di lapangan juga cukup rumit, guru dengan upaya yang sedemikian rupa masih belum mencapai tujuan pembelajaran dengan maksimal. Karena adanya berbagai macam kendala, dan hambatan. Bahkan belakangan telah terdengar resiko besar dalam pelaksanaan pembelajaran daring sebagaimana terpapar di headline news Nusantara di bawah ini: 


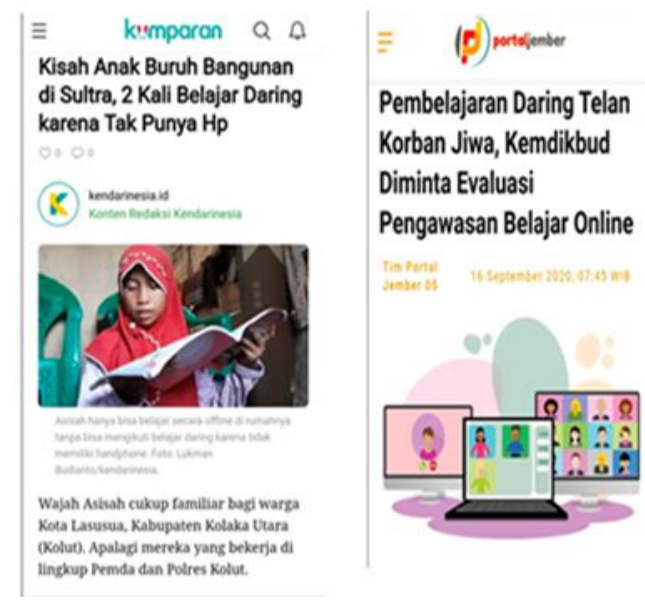

Gambar. 1. Headline News

Gambaran diatas sangat jauh dari tujuan pendidikan untuk dapat mencerdaskan kehidupan bangsa baik disisi guru, siswa dan orang tua. Sehingga dengan fenomena yang terjadi peneliti ingin mengetahui lebih rinci tentang permasalahan-permasalahan yang dihadapi guru PAUD dalam melaksanakan pembelajaran daring pada masa pandemi covid-19 khususnya di Kecamatan Tenayan Raya.

\section{Metode Penelitian}

Penelitian ini merupakan penelitian deskriptif dengan menggunakan pendekatan kuantitatif. Dalam penelitian ini variabel yang akan dideskripsikan permasalahan guru PAUD pada pembelajaran daring. Penelitian ini akan dilakukan pada bulan November 2020 hingga Oktober 2021 di PAUD Kecamatan Tenayan Raya.

Subjek dalam penelitian ini adalah seluruh guru PAUD yang ada di Kecamatan Tenayan Raya yang berjumlah 37 orang. Karena jumlah sampel kurang dari 100 maka semua guru menjadi sampel penelitian. Adapun teknik pengambilan sampel yaitu total sampling. Pengumpulan data dalam penelitian ini menggunakan kuisioner dan dokumentasi. 
Sebagai ahkir dari suatu proses peneltian adalah analisis data, yaitu pengolahan data secara kuantitatif dan analisis secara deskriptif karena penelitian ini bersifat gambaran dan menjelaskan mengenai permasalahan yang ada. Pengolahan data dilakukan setelah semua data terkumpul melalui lembar observasi untuk guru dan untuk anak. Data yang telah terkumpul diolah dengan langkah-langkah sebagai berikut:

1. Memeriksa kelengkapan isian data instrumen yang telah diterima dari validator, guru dan sampel penelitian dalam hal ini anak.

2. Membuat tabel pengolahan data.

3. Menskor dan menghitung jumlah hasil observasi dari responden serta memasukan dalam tabel pengolahan data.

4. Menganalisis data yang telah diperoleh.

Setelah data diolah ditetapkan kriteria penilaian masingmasing data yang diperoleh yang mengacu pada batasan pengelompokkan kriteria pengolahan data adalah sebagai berikut:

Tabel 1 Kriteria Permasalahan Guru PAUD (Riduwan, 2009)

\begin{tabular}{cc}
\hline \multicolumn{1}{c}{ Skor } & Kriteria \\
\hline $76 \%-100 \%$ & Tidak Ada \\
\hline $51 \%-75 \%$ & Sedikit \\
\hline $26 \%-50 \%$ & Banyak \\
\hline $0 \%-25 \%$ & Sangat Banyak \\
\hline
\end{tabular}

\section{Hasil dan Pembahasan}

\section{Hasil}

Berdasarkan hasil pengolahan data yang telah dilakukan didapat hasil sebagai berikut:

Tabel 2. Hasil Penelitian

\begin{tabular}{clcc}
\hline No & \multicolumn{1}{c}{ Indikator } & Persentase $(\%)$ & Kategori \\
\hline 1 & Pengorganisasian materi & 60,36 & Sedikit \\
\hline 2 & Komunikasi (daring) & 48,65 & Banyak \\
\hline 3 & Penguasaan dan antusiasme & 49,77 & Banyak \\
\hline 4 & Sikap positif anak & 67,91 & Sedikit \\
\hline
\end{tabular}




\begin{tabular}{cccc}
\hline No & Indikator & Persentase $(\%)$ & Kategori \\
\hline 5 & Keluwesan pembelajaran & 74,16 & Sedikit \\
\hline 6 & Hasil belajar & 49,10 & Banyak \\
\hline
\end{tabular}

Tabel di atas mendeskripsikan tentang permasalahan guru PAUD pada pembelajaran daring di masa pandemi. Berdasarkan tabel rekapitulasi terlihat bahwa indikator pengorganisasian materi memperoleh persentase $60,36 \%$ tidak jauh berbeda dengan indikator sikap positif anak yang memperoleh persentase $67,91 \%$ dan indikator keluwesan pembelajaran dengan persentase $74,16 \%$ yang artinya guru mengalami hanya sedikit permasalahan dalam mengorganisasikan materi, sikap positif anak, dan keluwesan pembelajaran. diperoleh persentse sebesar 49,42 dengan kategori belum paham.

Hal ini berbeda dengan hasil rekapitulasi pada indikator komunikasi (daring) yang mendapat persentase $48,65 \%$ dengan kategori banyak. Guru mengalami banyak permasalahan komunikasi (daring) baik dengan orang tua dan anak. Selanjutnya pada indikator penguasaan dan antusiasme perolehan persentase sebesar $49,77 \%$ yang masuk dalam kategori banyak. Hal ini berarti guru mengalami banyak kendala karena sebagian besar guru masih kesulitan membuat pembelajaran berupa video/slide baik disebabkan karena fasilitas yang tidak memadai maupun keterampilan yang tidak mendukung. Begitu juga indikator hasil belajar dengan persentase $49,10 \%$ yang dikategorikan banyak hal ini saling berhubungan, dengan ragam permasalahan yang terjadi pada guru tentu saja berpengaruh pada hasil belajar anak.

\section{Pembahasan}

Permasalahan lain yang banyak dialami guru dalam melaksanakan pembelajaran daring pada masa pandemi Covid-19 
di Kecamatan Tenayan Raya yaitu pada indikator penguasaan dan antusiasme. Sebagian besar guru masih kesulitan membuat pembelajaran berupa video/slide/animasi sederhana baik disebabkan karena fasilitas yang tidak memadai maupun keterampilan guru yang terbatas. Dikalangan guru sendiri berkembang pemikiran bahwa pemanfaatan teknologi canggih/ mutakhir, seperti internet, menjadi "beban tambahan" atau merepotkan (Koesnandar, dalam Siahaan, 2005).

Berdasarkan hasil penelitian diketahui juga bahwa anak merasa bosan saat pembelajaran daring dimasa pandemi covid19 berlangsung. Hal ini dikarenakan anak tidak mendapat video/ slide/ animasi yang menarik, anak juga tidak dapat berinteraksi langsung bersama teman dan guru, sehingga beberapa anak tidak mengikuti pembelajaran daring dari awal sampai akhir.

Selanjutnya dengan banyak kendala yang guru dapatkan dalam proses pembelajaran daring pada masa pandemi Covid-19 di Kecamatan Tenayan Raya tentu saja berpengaruh pada hasil belajar anak. Bagi guru PAUD yang terbisa melakukan pembelajaran secara tatap muka, kondisi ini memunculkan ketidaksiapan pembelajaran baik guru maupun anak. Agar sistem pendidikan jarak jauh dapat diselenggarakan dengan baik, maka harus memperhatikan berbagai komponen antara lain bahan, produksi bahan belajar, distribusi bahan belajar, dukungan belajar, penilaian peserta didik, pengolahan administrasi dan mekanisme umpan balik (Perry \& Rumble, dalam Warsita, 2007).

\section{Kesimpulan}

Terdapat permasalahan dalam proses pembelajaran daring pada masa pandemi Covid-19 di Kecamatan Tenayan Raya. Untuk indikator pengorganisasian materi, sikap positif anak, dan 
keluwesan pembelajaran berada dalam kategori sedikit. Sedangkan indikator komunikasi (daring), penguasaan dan antusiasme dan hasil belajar dikategorikan banyak.

\section{Daftar Pustaka}

Badru Zaman, dkk. (2007). Media dan Sumber Belajar. Jakarta: Universitas Terbuka.

Dermawan dan Pernasih. (2011). Kurikulum dan Pembelajaran. Jakarta: Raja Grafindo.

Gordon. A. M \& Browne. K. M. (2011). Beginning and Beyond, Foundation in Early Childhood Education, 8th Edition. USA: Wadsworth Cengage Learning

Helmawati. (2015). Mengenal dan Memahami PAUD. Bandung: PT Remaja Rosdakarya.

Ismail, Andang. (2009). Education Games. Yogyakarta: Pro-U Media

Sanjaya, Wina. (2006). Strategi Pembelajaran Berorientasi Standar Proses Pendidikan. Jakarta: Kencana Prenada Media Group.

Wiyani, Novan dan Barnawi. (2014). Format PAUD. Yogyakarta. Ar-Ruzz Media

Yaumi, Muhammad. (2010). Prinsip-prinsip Desain Pembelajaran. Jakarta: Kencana

Yus, Anita. (2011.) Penilaian Perkembangan Belajar Anak Taman Kanak-kanak. Jakarta: Kencana. 